\title{
JUURNAL.RU
}

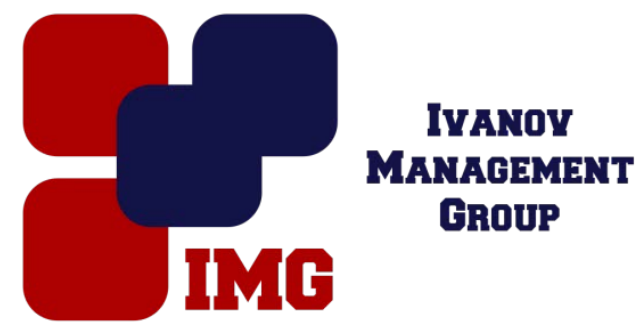

Кригалева В.Н.

Иркутский Государственный Университет

Иркутск, Россия

doi: 10.18411/lj-28-02-2017-2-06

idsp 000001:lj-28-02-2017-2-06

\section{Экономический пояс Шелкового пути: проблемы и перспективы}

\section{Аннотация}

В статье рассматривается и анализируется китайская стратегия экономического пояса Шелкового пути, её проблемы и перспективы.

Ключевые слова: экономический пояс; Шелковый путь; Евразийский Экономический союз; Китай; мировая экономика.

\section{Abstract}

In article author considers and analyzes Chinese strategy of Silk Road Economic Belt, its problems and perspectives.

Key words: economic belt; Silk Road; Eurasian Economic Union; China; world economy.

Стратегия экономического пояса Шелкового пути, выдвинутая председателем Китайской Народной Республики Си Цзиньпином осенью 2013 года, является частью проекта под названием “Один пояс - один путь" и показателем того, что экономическая политика КНР серьезно обновится, поскольку основной задачей руководства Китая является постоянный поиск устойчивых путей развития страны под руководством КПК [Баринкова, Кремнёв]. Данный проект также включает в себя стратегию морского Шелкового пути и подразумевает под собой возрождение Великого Шелкового пути, который внес неоценимый вклад в развитие отношений между Востоком и Западом. В рамках данной стратегии рассматривается создание трех трансевразийских экономических коридоров: северного (Китай - Центральная Азия - Россия Европа), центрального (Китай - Центральная и Западная Азия - Персидский Залив и Средиземное море) и южного (Китай - Юго-Восточная Азия - Южная Азия Индийский океан) [Ремыга, 2015].

Считается, что проект “Один пояс - один путь” надолго определит внешнеэкономическую политику Китая. Основная цель данной концепции заключается в укреплении партнерских отношений между Азией, Европой и Африкой. Вопрос о предполагаемых «пользе» и «вреде» проекта для различных стран-участников и не участников постоянно поднимается в политическом 
дискурсе разных стран [Кузнецова].

Главным сотрудником Китая в реализации проекта стал Евразийский Экономический Союз: они могут сотрудничать в усовершенствовании транспорта для развития инфраструктуры, в сфере строительства, выработке ресурсов и новых технологий в рамках ЭПШП. О решении России принять участие в стратегии Экономического пояса шелкового пути заявил в 2015 году вице-премьер РФ Игорь Шувалов в ходе Азиатского экономического форума: "Мы рады возможности наращивать сотрудничество в формате Китай и Евразийский союз... Свободное движение товаров и капиталов в рамках ЕАЭС сближает экономики Европы и Азии, что перекликается с инициативой экономического пояса Шелкового пути, выдвинутой китайским руководством. Мы в РФ уверены, что совместная работа по развитию евразийского партнерства и экономического пояса Шелкового пути создаст дополнительные возможности для развития стран Евразийского союза и Китая".

Большую роль в реализации проекта играют инвестиции. По данным ТАСС, в целях финансирования проектов концепции "Один пояс — один путь" в 2014 г. в Китае были созданы два новых финансовых института: Азиатский банк инфраструктурных инвестиций (АБИИ) и Фонд Шелкового пути. Основными источниками финансирования фонда являются Государственная администрация валютных поступлений Китая, Китайская инвестиционная корпорация, Экспортно-импортный банк Китая и Банк развития Китая. Начальный капитал фонда составил \$10 млрд.

Данная китайская концепция нацелена на то, чтобы создать такую инфраструктурную сеть, которая в будущем свяжет всю планету и при которой в рамках глобализирующегося мирового сообщества [Макеева] выигрывают все её участники, а не только КНР.

"Выдвинутая Китаем инициатива, отражающая идеалы и ценности всего человеческого сообщества, - попытка поиска новой модели международного взаимодействия, которая даст положительный импульс мировому развитию и будет способствовать поддержанию всеобщего мира на планете. Китай не претендует на экономическую гегемонию и не заявляет о своей исключительности. Теоретические основы, на которых базируются главные положения концепции, согласуются с основными целями Устава ООН и пятью принципами мирного сосуществования. Проект полностью открыт для участия всех членов международного сообщества и не ограничивается территорией, исторически относящейся к древнему Шелковому пути.” [Кулинцев, 2015]. Такого рода включение идеалов и ценностей в экономический аспект соответствует духовным основам хозяйственной культуры Китая [Кобжицкая].

Существует ряд проблем, которые могут встать на пути успешной реализации данного проекта. Для их устранения всем участникам глобальной сети придется приложить усилия. Особенно это касается государств-участников ЕАЭС, которым в реализации проекта отводится особая роль, так как они являются наиболее перспективными коридорами из Китая в Европу. ЕАЭС предстоит решить проблемы, связанные с железнодорожным и автомобильным транспортом, например, стоимость перевозок по железнодорожным путям, срок таможенных проверок и низкое качество автомобильных дорог.

Не стоит забывать и о тех проблемах, позаботиться о которых ради общего блага должно каждое государство, принявшее участие в проекте “Один пояс - 
один путь”. Для осуществления концепции необходимо развитие инфраструктурной связи стран, внедрение общих принципов сертификации [Кумялова], финансовое объединение и политическая организация.

На данный момент проект, развивается медленно, но верно. Осуществляется политическая и организационная подготовка инициативы Китая. Правительство КНР активно обсуждает концепцию на международных конференциях с лидерами других стран. Были подписаны меморандумы о взаимопонимании и согласованы планы экономического взаимодействия со многими странами, была оказана коммуникационная поддержка по ключевым проектам сотрудничества [Кулинцев, 2015]. Как сообщает ТАСС, 18 января 2017 года в Лондон прибыл первый товарный поезд из КНР, который проехал по Новому Шелковому пути и прошел по территории Китая, Казахстана, России, Белоруссии, Польши, Германии, Бельгии, Франции и Великобритании. Если бы вместо поезда товары отправились в Лондон морем, они бы прибыли только 1 марта.

Если решить ряд проблем, существующих на данный момент, то благодаря данному проекту Китаю удастся решить проблемы отсталости Западных районов, укрепить положение на европейских и азиатских рынках, освоить новые рынки, сократить время, расходуемое на перевозку товаров. Как сообщает Вести Финанс, реализация проекта позволит сократить срок доставки грузов по железной дороге из Китая в Восточную Европу до 11 дней.

Также Китаю удастся расширить свои железнодорожные и строительные компании за границами КНР и тем самым обеспечить их работой на долгое время.

Для России также существуют перспективы в реализации проекта. На фоне сложившихся сложных отношений с Западом, Россия нуждается в укреплении отношений с Китаем для дальнейшего сотрудничества. Проект поможет упрочить России статус крупной транзитной страны, если она встроится в трансевразийские коридоры.

Для международного сообщества данный китайский проект может стать началом нового финансового мироустройства. При успешной реализации он станет первоначалом международных отношений, которые будут основываться на партнерстве и выигрыше всех государств-участников. 


\section{Литература}

1. Баринкова А.В., Кремнев Е.В. К вопросу о типологических характеристиках партийной системы КНР // Китай: история и современность: материалы IX Международной научно-практической конференции. Ответственный редактор С. В. Смирнов. 2016. С. 220-225.

2. Кобжицкая О.Г. Духовные основы хозяйственной культуры. Диссертация на соискание ученой степени кандидата философских наук / Иркутский государственный университет. Иркутск, 1999. 210 с.

3. Кузнецова О.В. Прагматический потенциал английских прилагательных со значением «полезный»/«вредный» в политическом дискурсе // В мире научных открытий. 2014. № 5.2 (53). С. 676-684.

4. Кулинцев Ю. В. “Один пояс - один путь”: инициатива с китайской спецификой. Российский Совет по Международным Делам. http://russiancouncil.ru/blogs/riacexperts/?id 4=1868 (22 мая. 2015)

5. Кумялова О.В. Сопоставительный анализ сертификационных стандартов алкогольной продукции РФ и КНР // Китай: история и современность: материалы IX Международной научно-практической конференции. Ответственный редактор С. В. Смирнов. 2016. С. 101-105.

6. Макеева С.Б. Особенности социологического осмысления процесса глобализации современного мирового сообщества // Сборник статей по итогам научноисследовательской работы института социально-политических систем Читинского государственного университет за 2009-2010 гг. Чита, 2010. С. 15-23.

7. Ремыга В. Н. Экономический пояс Шелкового пути // Вестник Финансового журнала. 2015. № 6 . 